\title{
TRYPARSAMIDE IN NEUROSYPHILIS*
}

By R. C. L. BATCHELOR, M.B., F.R.C.S.(Edin.)

THIs paper should really have been given by Dr. Robert Lees, but he went off to the Army and left me the responsibility for it as a parting gift. Rather rashly and in an unguarded moment I accepted this duty: I did not realise then, as I do now, how much A.R.P. and other urgent matters would eat into my time. The consequence has been a hectic hurry and rush to get the paper anywhere near to completion, and the plan originally adopted has become progressively less extensive and ambitious.

At the very outset, and not at the end or as an afterthought, I wish to express my indebtedness to Dr. G. M. Thomson, my clinical assistant, to Nurse Marshall, my nurse almoner, and to my secretary, Mr. Keith. Without the energetic and loyal co-operation of these three this paper could not possibly have been finished in time. I have to thank Dr. Robert Lees, too, for helpful suggestions.

Tryparsamide is one of the most attractive drugs in our armamentarium because there is an element of mystery about its action. Here is no potent spirochæte killer and yet an agent which is admittedly our first choice in the treatment of neuro-syphilis. It is mild, of low toxicity, and given in relatively enormous doses, and yet it belies its mildness by occasionally destroying sight. It cannot kill the spirochætes in a primary chancre, but it can penetrate the meninges and it can produce effective concentrations of arsenic in the parenchyma of the brain. This therapeutic paradox has been alternately acclaimed as likely to cure G.P.I. and thus deprive syphilis of its greatest horror, then damned by faint praise, and finally given general acceptance in Englishspeaking countries as indispensable in syphililogy.

Fifteen and a half years have now passed since try-

* Paper read at M.S.S.V.D. Annual General Meeting on July I3th, I940. 
parsamide was put on the market, and this period is sufficiently long to promcte the stabilisation, if not the definite settlement, of medical opinion. If first impressions were too favourable, subsequent experience has been extensive enough. to correct the balance. In planning this paper I set out with the intention of finding out the fate of as many as possible of our early cases. Were they alive or dead, sane or insane, sighted or blind, able to work or not? I resolved to assume the acceptance of much that has been attested by numerous clinical studies, for example the production of remissions in a large proportion of cases of early general paralysis and tabes.

This study has been founded on certain positions which must now be defined. First, in the great majority of the cases quoted, intramuscular bismuth has been extensively used along with the intravenous tryparsamide and used concurrently in courses of dual therapy separated by rest intervals. Thus the results produced are not the results of the use of tryparsamide alone but of tryparsamide and bismuth, although some evidence will be adduced to show that these results are not materially different from those obtained from tryparsamide alone.

In order to establish a criterion on which to found a reliable judgment, it will be useful to postulate the results which we may legitimately expect from the use of tryparsamide, and then to ascertain whether or not the drug has come up to expectations. In this connection the duration of the attack on the central nervous system is of primary importance. In the early cases which are usually in the younger patients we may justifiably expect the elimination of the spirochætes before they have had time to kill the neurones, and therefore alleviation of symptoms and arrest of the degenerative processes. In the later cases which are usually in older patients we must recognise that irreparable damage has occurred before the commencement of treatment. And this irreparable damage, by its very nature, holds out a threat for the future. Nerve cells and their processes have been killed. Through the interweaving of their processes and by juxtaposition, the dead neurones exercise a harmful influence on the health of the neighbouring neurones and form a focus from which degeneration may spread, even although the spirochæes which caused the original destruction have all been killed off. 


\section{TRYPARSAMIDE IN NEUROSYPHILIS}

In tryparsamide therapy, one of the main items of interest is the action of the drug on the optic nerve, and in this connection also it will be well to survey clearly the conditions which exist when tryparsamide is exhibited. In some of the clinical reports already published, in the classification of the cases, a group is established of those cases which, prior to the commencement of treatment, had what is described as " normal visual apparatus." But it may well be asked, "Can the visual apparatus of a late neuro-syphilitic ever be justly regarded as normal, even if the visual acuity and fields of vision are satisfactory ?" Surely in these cases there must often be vascular changes, thickening and adhesion of the meninges and perivascular infiltration in the parenchymatous tissues which combine to devitalise the optic nerves and tracts throughout their whole extent. Such devitalised tissues will undoubtedly show a lowered resistance to an admittedly neurotropic drug like tryparsamide. Where the histopathological changes, at first hidden and silent, have reached the greater degree of causing pallor of the optic disc, or diminished visual acuity and contracted fields, then the lowering of resistance also will have become more pronounced and such cases will present a still lower resistance to a neurotropic drug. Tryparsamide, like other organic arsenicals with an amino- or substituted amino group in the para position to the arsenic, can cause optic atrophy in non-syphilitic subjects, and, bearing in mind the inevitability of lowered resistance in syphilis, it is only to be expected that it will more easily cause optic atrophy where the syphilis has definitely attacked the nervous tissues. This expectation is borne out by clinical findings.

Tryparsamide treatment of neuro-syphilis was started in the Edinburgh Clinic in I925, and the present study is largely a follow-up investigation of those cases who were treated in the early days or who have been under observation for long periods. When tryparsamide was started, many of the original cases had already received considerable treatment with neoarsphenamine ("9I4") and bismuth or mercury. Later on tryparsamide and bismuth predominated, though not infrequently courses of neoarsphenamine ("9I4") or sulfarsphenamine were interpolated especially if the blood Wassermann proved resistant. Also malaria inoculation was frequently used to reinforce the tryparsamide, and this introduces another 


\section{BRITISH JOURNAL OF VENEREAL DISEASES}

factor modifying the value of the evidence as a study of the individual action of tryparsamide alone.

Many of the patients we have been unable to trace through change of address or other causes. In the case of those who have gone to mental institutions we have not always been able to elicit co-operation sufficient for the purposes of our study. Academic inquiries are apt to be resented when invasion is knocking at the door. But even the demonstration of gaps in continuity may be of value : in these cases, both the welfare of the individual and the possible social interactions demand that continuous observation be maintained throughout the patient's lifetime.

Since the introduction of tryparsamide there have been many publications dealing with clinical investigations of groups of cases. This sifting of material and the accumulated experience of more than a decade and a half has resulted in a crystallisation of opinion and substantial agreement on many points. I propose now to enumerate these points on which we are in general agreed. At the outset I made a mental note of them, and resolved to try to adduce some new evidence. Many of the published papers have dealt with cases observed over periods of up to four years but comparatively few attempts have been made to trace the history of patients for ten or twelve years or longer.

As an illustration of how an extended period of observation produces an alteration of opinion I may quote a case of juvenile general paralysis (W.B.) about whom the late. Mr. Lees in I928 wrote as follows :-

"The following example will possibly emphasise more than anything I can say what can be done with this drug :-

"The first case was referred to me almost three years ago by Professor Bramwell as a well-marked case of juvenile general paralysis of the insane, age 23. He had all the symptoms of a rapidly advancing paretic with loss of both bladder and rectal reflexes. He could neither read nor write, disorientation was marked, he was childish in his habits, very facile and had not at any time been able to do any work. His blood and cerebrospinal fluid gave a strong positive Wassermann reaction, and his cerebrospinal fluid also showed a strong paretic Goldsol curve. He was treated initially with Silver Salvarsan and after his second injection developed a very severe hæmorrhagic encephalitis and was unconscious for four days. The only possibility in the way of treatment that appeared feasible and justifiable was bismuth and yet we felt this was not likely to influence so advanced a case. 


\section{TRYPARSAMIDE IN NEUROSYPHILIS}

With his parents' consent he was given tryparsamide although we knew that he had definite optic atrophy. The results have been remarkable. He is now able to read and write, he has control of both sphincters and for the past nine months he has been able to work and earn his living. Both his blood and cerebrospinal fluid give a negative reaction and we hope to be able to keep them negative by treating him over a sufficiently long period.

"To give you some idea of the amount of treatment required he has had a total of over I6o gm. tryparsamide and close on 30 gm. of bismuth in the time he has been under our care. The optic atrophy has not in any way advanced and he has had no toxic ocular symptoms whatever during the whole course of his treatment."

This patient is still alive, now aged 38 , but an inmate of an asylum. He was admitted to an asylum in I93I at age 29. His general health is good and he is able to do routine simple institution work. Mentally he is facile and demented and his mental condition is deteriorating progressively. His optic atrophy is also slowly progressing and his vision is becoming worse. Up to I93I, while under our care, he received tryparsamide as already noted and since I93I has had sulpharsphenamine, bismuth, mercury and neoarsphenamine.

In spite of the favourable impression produced in the early stages of this case, Mr. Lees had no illusions regarding the limitations of tryparsamide. Indeed, in the same article he wrote- " We are not in a position to claim, and are far from claiming, that it should be exhibited in all cases of neurosyphilis, and we doubt whether in established cases of G.P.I. it gives as good results as malarial therapy," and again, "I would not for one minute claim that every case is successful even in the earlier types of neurosyphilis. When tryparsamide fails to influence favourably either the clinical or the serological aspect of the case, we have another weapon at our disposal in malarial therapy."

It has been fairly conclusively established that tryparsamide can achieve the following results: in about 50 per cent. of cases of early G.P.I. and 35 to 60 per cent. of tabes it can produce definite clinical improvement amounting to remission in a considerable proportion; also it can produce steady improvement in all the tests of the cerebrospinal fluid, the cell count and the globulin being the first to improve, and the Wassermann and colloidal gold the last. Moreover it is a stimulator of 
metabolism and causes increase in weight and in general well-being. It is of low toxicity, its use being associated with few untoward reactions, but it may damage the optic nerve. Most of us will accept these claims and I have therefore set out to answer this question, "Over a long period of review, how does tryparsamide treatment modify the expected course of G.P.I. and tabes, how does it affect life over a decade or a decade and a half ?" I have not concerned myself so much with the early forms of neuro-syphilis, as the earlier attacks, often concentrated on the meninges, are more amenable to ordinary anti-syphilitic treatment with neoarsphenamine, and bismuth. Cerebral syphilis not classified as $P$. (paresis), T.P. (tabo-paresis) or T. (tabes) has also been excluded from this paper.

It has been stated that tryparsamide should not be given to pregnant women because of the possible danger to the optic nerves of the child in utero. I cannot produce a large number of cases where tryparsamide has been exhibited in pregnancy, but can quote four instances where the drug has been given in amounts up to 38.5 gm. and up to within six days of confinement without causing any injury to the optic nerves of the child. The evidence afforded by these few cases, therefore, does not corroborate the view that tryparsamide treatment of the expectant mother is likely to cause optic atrophy in the child in utero.

The method adopted in the follow-up of city cases not attending or only coming for observation at long intervals has been to write asking them to come for an interview or to send the nurse almoner to visit them in their homes. Those who came for interview were seen either by myself or Dr. Thomson, and the visiting nurse obtained as full particulars as possible during a brief conversation. Information regarding cases outside Edinburgh or in institutions was obtained by sending to the patient or to the relatives or to the institution a questionnaire with spaces for replies to the questions asked. The information obtained in these ways has been incorporated in a series of statistical tables which will now be described.

Tables I and II give a general analysis of acquired infections in men and women which have resulted in paresis, tabo-paresis and tabes. The cases are grouped according to the year in which tryparsamide was started, 


\section{TRYPARSAMIDE IN NEUROSYPHILIS}

and the numbers are given of those alive, dead and untraced. The numbers of those showing fundus oculi changes, such as optic atrophy and choroido-retinitis, are given, and the numbers of cases who developed intolerance in the shape of jaundice, or dermatitis or purpura.

Tables III to VIII give particulars of the living paretics, tabo-paretics and tabetics, both men and women, and show the year in which tryparsamide was started, the age group at the commencement of treatment, the average amount of tryparsamide administered, whether malaria was given, and the condition in I940, as to whether the patient was able to work or for any reason could not be traced. Under this last heading of "Condition in I940" the paretics are also subdivided into "Sane" and "Insane."

Tables IX and $\mathrm{X}$ deal with congenital infection in both sexes and give those diagnosed as paresis, taboparesis or tabes, the age group at commencement of treatment, the average amount of tryparsamide administered in grams, whether malaria was given, any fundus oculi changes, and the condition of the patients in r940, as to whether they were still alive and able to work or untraced.

Tables XI to XIV give details of the occurrence of optic atrophy in both acquired and congenital infections and in both sexes. Included in these details are the amount of tryparsamide administered, whether optic atrophy was present when tryparsamide was started, and, if present initially, whether it was slight, moderate or severe, and finally the degree of ultimate damage assessed as slight, moderate or severe.

The XVth and last table describes 4 cases in which tryparsamide was exhibited during pregnancy, and shows that in no case was there any resultant optic atrophy in the child.

An analysis of the particulars contained in these tables gives the following results:-

Table $I$. Of 280 male cases of late neurosyphilis resulting from acquired infection, 23.3 per cent. were paretics, $15 \cdot 3$ per cent. were tabo-paretics, and $6 \mathrm{I} \cdot 4$ per cent. were tabetics. The condition of these in I940 was that 57.5 per cent. were alive, I7.9 per cent. were dead, and 24.6 per cent. were untraced. The proportion showing fundus oculi changes was $22 \cdot \mathrm{I}$ per cent. 


\section{BRITISH JOURNAL OF VENEREAL DISEASES}

Cases showing intolerance were assessed as follows: jaundice 13.2 per cent., dermatitis 5.7 per cent., and purpura 0.3 per cent.

Table II.-Of 60 female cases of late neuro-syphilis resulting from acquired infection, 25 per cent. were paretics, 20 per cent. wẹre tabo-paretics, and 55 per cent. were tabetics. The condition of these in I940 was that 60 per cent. were alive, 8.3 per cent. were dead, and I9 per cent. were untraced. The proportion showing fundus oculi changes was 16.7 per cent. Cases showing intolerance were assessed as follows: jaundice $\mathrm{I} \cdot 6$ per cent., and dermatitis $\mathrm{I} \cdot 6$ per cent.

Table III shows that of 47 male paretics still alive in I940, 63.8 per cent. were able to work.

Table IV shows that of I3 female paretics still alive in I940, 53.8 per cent. were able to work.

Table $V$ shows that of $4 \mathrm{I}$ male tabc-paretics still alive in I940, 43.9 per cent. were able to work.

Table VI shows that of II female tabo-paretics still alive in I940, $72 \cdot 7$ per cent. were able to work.

Table VII shows that of 142 male tabetics still alive in I940, 50.7 per cent. were able to work.

Table VIII shows that of 32 female tabetics still alive in I940, $56 \cdot 2$ per cent. were able to work.

Table IX.-Of I8 male cases of late neuro-syphilis resulting from congenital infection, $6 \mathrm{I} \cdot \mathrm{I}$ per cent. were alive in I940, and $\mathbf{2 2 \cdot 2}$ per cent. were able to work.

Table $X$. Of 13 female cases of late neuro-syphilis resulting from congenital infection, 38.4 per cent. were alive in I940.

Tables XI to XIV. Of these tables dealing with optic atrophy, only Table XI contains a number of cases sufficient to allow of the deduction of useful conclusions. Table XI dealing with the occurrence of optic atrophy in male cases resulting from acquired infection shows that in 67.2 per cent. optic atrophy of varying degrees of severity was present when tryparsamide was started, and that in 73.7 per cent. the degree of ultimate damage was severe.

As two papers have to be discussed this afternoon I shall not attempt any detailed commentary on these figures. Bearing in mind the accepted prognosis of general paralysis, is it not very encouraging that in a fairly large group of cases treated between I925 and I936 or I937 


\section{TRYPARSAMIDE IN NEUROSYPHILIS}

the proportion still able to work in I940 should be as high as 63.8 per cent. ? In regard to the proposition, "Can tryparsamide fulfil reasonable expectations?" it would appear that the answer must be "Yes." All cases of late neuro-syphilis are irreparably and permanently damaged. No therapeutic agent can be expected to restore absent knee jerks or the light reflex in an Argyll-Robertson pupil. Dead tissue cannot be resuscitated by any drug, and may be the focus from which degeneration will extend. It cannot reasonably be expected of tryparsamide or any other drug that it will restore dead functions to life.

Moreover, spontaneous remissions are common in any form of late neuro-syphilis, but such remissions rarely last longer than six to twelve months. Tryparsamide can secure prolonged remissions, and powerfully slow down the inevitably advancing degeneration.

The danger of relapse even after prolonged treatment is illustrated by the following case of asymptomatic neuro-syphilis, particulars of which are now appended :-

Case No. B.9827.-Man, aged 27. First reported for examination on $23-5-32$ on account of slight balanitis with accumulation of smegma. Clinical examination otherwise entirely negative. Blood Wassermann (unexpectedly) strong positive. On 30-5-32, confirmatory blood Wassermann strong positive. From $30-5-32$ to 9-8-32 received in treatment $3.4 \mathrm{gm}$. "9I4" intravenously and $3 . \mathrm{I} \mathrm{gm}$. bismuth, intramuscularly. On I3-9-32, blood Wassermann still strong positive. From I3-9-32 to 26-12-32, received in treatment $4.8 \mathrm{gm}$. "9I4" and $2.3 \mathrm{gm}$. bismuth. On 24-I-33, blood Wassermann weak positive. On 29-I-33, cerebrospinal fluid tests : cells-2 per cmm.; globulin-increased a trace ; Wassermann-strong positive ; goldsolI2332I000o. On the same date, clinical examination of the central nervous system did not reveal any abnormality. Thereafter, from $\mathrm{I} 4-2-33$ to $29-12-36$, received I94 gm. tryparsamide and Io courses of bismuth to a total of $28.2 \mathrm{gm}$. The blood Wassermann became negative on 27-6-33 and remained consistently negative throughout fourteen repetitions up to $I-4-38$. The cerebrospinal fluid Wassermann became negative on I5-I2-35 and remained negative in two repetitions up to 2I-3-37 when for the first time the goldsol was also v.D. 


\section{BRITISH JOURNAL OF VENEREAL DISEASES}

completely negative. Injection treatment was stopped after 29-12-36. On 2I-6-38, the blood Wassermann was doubtful negative, and thereafter the serological tests up to 20-10-39 were in turn negative, very weak positive (Kahn \pm ), negative (Kahn \pm ), negative (Kahn $t$ ). Patient was given permission to marry and got married in February, I939. In October, I939, he was given permission for his wife to have children.

Then came the crash. On I5-4-40, he was transferred to a Corporation Hospital from the City Infectious Diseases Hospital where he had been for twelve days with a sore throat, headache and vomiting-on the diagnosis of cerebrospinal meningitis. $\mathrm{He}$ was unable to give any coherent history. On 4-4-40, it was thought that he had acute melancholia, and afterwards the provisional diagnosis of cerebral tumour was entertained. The cerebrospinal fluid Wassermann was now strongly positive. On 26-4-40, he was transferred to my ward in the Royal Infirmary. On that date the blood Wassermann and Kahn were both negative, and, on 28-4-40, the cerebrospinal fluid tests were: Cells-I per $\mathrm{cmm}$.; globulin-no increase; Wassermann-weak positive; goldsol-00I23100oo. At times he was completely unresponsive, but when he did respond it was apparent that he was disorientated, his attention unstable, his memory defective and hallucinations were marked. Fever therapy by inductopyrexia was begun and combined with tryparsamide and bismuth. After the sixth pyrexial treatment he was much more rational, began to play cards and shaved himself. On $26-5-40$, he attempted to jump over the ward balcony and also attempted to get out of a window. On 28-5-40, he was transferred to the ward for cases requiring special supervision. He had four more pyrexial treatments making ten in all up to I9-6-40. Soon afterwards he was certified insane and transferred to an asylum.

This shattering and disillusioning experience makes one very chary of regarding tryparsamide, or "9I4" or bismuth or any combination of them as a cure for neurosyphilis even in its early asymptomatic stage in a young patient. The signs of serological relapse should have been regarded as an indication for the resumption of treatment, and the eventual calamity might have been averted by yearly maintenance courses. 


\section{TRYPARSAMIDE IN NEUROSYPHILIS}

Perhaps the most useful conclusion I can draw from this study is that there are gaps in the continuity of observation of these cases which should be closed up. All of them require observation throughout life, and yet they drift away and into and out of institutions and are too often lost sight of. And this criticism is the more damaging if we believe, as these statistics appear to show, that tryparsamide exerts its most favourable influence when persisted with for prolonged periods and given up to a very large total dosage. One of our cases has received over $600 \mathrm{gm}$. of the drug, and suitable cases can receive from 300 to $500 \mathrm{gm}$. of the drug with apparent benefit. We seldom exceed an individual weekly dose of $3 \mathrm{gm}$. for a man or $2 \mathrm{gm}$. for a woman, and the usual course comprises Io to 12 or 15 injections, making a total in the course of 20 to $30 \mathrm{gm}$. or more.

Optic atrophy is a real danger, and the whole optic tract in a late neuro-syphilitic must be regarded as tissue which will offer a lowered resistance to a drug which can damage really healthy optic nerves. But this danger need not be a deterrent, if all reasonable precautions are observed and these include the initial and repeated determination by an expert ophthalmologist of the visual acuity and the fields of vision. Not even an expert can detect impending trouble by an ophthalmoscopic examination. If caution be exercised in its use, tryparsamide is an effective and reliable drug in putting a brake on the downward progress of late neuro-syphilis. Its effect naturally is greatest in young persons and in the earlier cases. In the strict sense of the word it is not a cure for late neuro-syphilis, nor can it justifiably be termed "therapeutic T.N.T."

With regard to the combined action of bismuth and malaria as vitiating the value of this study of the action of tryparsamide, I have observed cases where little bismuth was exhibited and where malaria was not used, and the results in these cases were approximately similar to those already quoted. Also I believe from my experience that tryparsamide if used persistently can slowly reduce positivity of the blood Wassermann. Experience too has led to the general decision that the best results are obtained where tryparsamide is combined with bismuth and malaria and where "9I4" is used if the blood Wassermann is resistant. 


\section{BRITISH JOURNAL OF VENEREAL DISEASES}

In conclusion I would like to enliven these dusty and laborious statistics by giving you thumb-nail sketches of some of our more interesting cases. First, No. A.6974, a case of juvenile general paralysis, who first came to us from a medical ward in March, 1927, at the age of 20 . The history was that he was quite well till he fell off a lorry six weeks before and landed on his head. Two weeks later he had pains in the stomach. On examination he appeared to be very pleased with himself, but was very stupid and slow to understand what was said. Sunken bridge of nose. Hutchinsonian teeth. Speech monotonous, but repeated test words correctly. Pupils regular, but unequal. No reaction to light or accommodation in right eye ; left eye, both reactions very slightly present. Knee jerks-left, brisk, right, sluggish. Ankle jerks-left, normal, .right, absent. Blood Wassermannstrongly positive. Cerebrospinal fluid tests-cells 9 per $\mathrm{cmm}$., globulin slight increase, Wassermann strongly positive, goldsol 5555533 I000. In treatment he received malaria and $76 \mathrm{gm}$. of tryparsamide. His mother states he is now in perfect health, in the Army, and supports her. He is now aged 33 and it is thirteen years since his treatment was started.

Second, No. 6462, a case of juvenile general paralysis who first came to us from a medical ward in January, I927, at the age of I4. The history was that he was a normal child till age I3. Since then he had become fatter but had not grown. Voice becoming nasal. Mentally dull. Unable to concentrate. Emotional without provocation. Doesn't join in sport, but sits in the house all day. Appetite ravenous. Table manners becoming primitive. Frequency of micturition. Mother's blood Wassermann negative. On examination, fairly definite pegging of teeth, speech slurred and monotonous. Pupils, equal, but left slightly irregular; react sluggishly to light and accommodation. Reflexes exaggerated. Fine tremor of arms and legs. Rombergism - tendency to fall backwards. Gait - tendency to drag feet, slightly stamping. Secondary sexual characters underdeveloped, no pubic hair, genitals small. Blood Wassermann-strongly positive. Cerebrospinal fluid tests - cells 27 per cmm., globulin increased +, Wassermann strongly positive, goldsol 5553I I0000. In treatment he received malaria and $35.5 \mathrm{gm}$. of tryparsamide. At present in July, I940, 


\section{TRYPARSAMIDE IN NEUROSYPHILIS}

thirteen and a half years since his treatment was started, his general health is good, he is very cheery but childish. He cannot work but is able to go messages for his mother, who writes about him as follows: "He has never turned quite in his right normal way, always very cheery but childish in some ways. He never has a day's illness, out of doors every day of the week. There is still a little ' mentalness.' He has a grand memory. All that he does is go messages for myself. $\mathrm{He}$ is now 27 years old and a fine looking young man. I am so sorry that he didn't come quite all right."

My final conclusion is that the evidence adduced affords corroboration for the claim that tryparsamide can retard for ten, twelve or more years the progress of grave advancing destruction of the central nervous system due to late neuro-syphilis, and that in doing so it promotes well-being and adds to the sum-total of human happiness.

\section{TABLE I.-ACQUiRED INFECTION-MeN}

Cases of Neurosyphilis as shown below, Years when Treatment Commenced, Present State, and Numbers showing Intolerance

\begin{tabular}{|c|c|c|c|c|c|c|c|c|c|c|}
\hline \multirow{2}{*}{$\begin{array}{l}\text { Year } \\
\text { Trypar- } \\
\text { samide } \\
\text { Started }\end{array}$} & \multicolumn{3}{|c|}{ Number of Cases } & \multicolumn{3}{|c|}{ Condition in 1940} & \multirow{2}{*}{$\begin{array}{l}\text { Fundus } \\
\text { Oculi } \\
\text { Changes }\end{array}$} & \multicolumn{3}{|c|}{ Intolerance } \\
\hline & PAR.* & T.P.* & Tabes & Alive & Dead & $\underset{\text { traced }}{\text { Un }}$ & & Jaundice & $\begin{array}{c}\text { Derma- } \\
\text { titis }\end{array}$ & $\begin{array}{l}\text { Pur- } \\
\text { pura }\end{array}$ \\
\hline $\begin{array}{l}1925 \\
1926\end{array}$ & 2 & $\begin{array}{l}3 \\
\mathbf{I}\end{array}$ & $\begin{array}{l}2 \\
2\end{array}$ & $\begin{array}{l}5 \\
3\end{array}$ & & 2 & $\begin{array}{l}\mathbf{I} \\
\mathbf{I}\end{array}$ & & & \\
\hline 1927 & 4 & 5 & 9 & 6 & 2 & Io & 6 & 3 & 2 & \\
\hline 1928 & 3 & 2 & I4 & 7 & 4 & 8 & 5 & I & 2 & I \\
\hline 1929 & Io & 2 & I 7 & 17 & 8 & 4 & 4 & 3 & 2 & \\
\hline 1930 & 5 & 2 & I I & 13 & 3 & 2. & 2 & 6 & $\mathbf{I}$ & \\
\hline I93I & 10 & 4 & 27 & 27 & 8 & 6 & 8 & 4 & 2 & \\
\hline 1932 & 8 & 7 & I 7 & 14 & 9 & 9 & I I & 5 & & \\
\hline 1933 & 9 & I & 22 & 18 & 4 & ro & 9 & 3 & $\mathbf{I}$ & \\
\hline I934 & 4 & 4 & I8 & I5 & 5 & 6 & 2 & 2 & 2 & \\
\hline 1935 & 5 & 6 & I 5 & 16 & 4 & 6 & 7 & 8 & I & \\
\hline 1936 & 3 & 4 & 7 & 12 & I & $\mathbf{I}$ & 5 & $\mathbf{I}$ & 3 & \\
\hline r937 & $\mathbf{r}$ & 2 & 8 & 7 & $\mathbf{I}$ & 3 & $\mathbf{I}$ & & & \\
\hline \multirow[t]{2}{*}{1938} & $\mathbf{I}$ & & 3 & $\mathbf{I}$ & $\mathbf{I}$ & 2 & & $\mathbf{I}$ & & \\
\hline & 65 & 43 & I 72 & r6r & 50 & 69 & 62 & 37 & I6 & $\mathbf{I}$ \\
\hline & \multicolumn{3}{|c|}{ Total 280} & & & & & & & \\
\hline Per cent. & $23 \cdot 3$ & $15 \cdot 3$ & $6 I \cdot 4$ & $57 \cdot 5$ & $17 \cdot 9$ & $24 \cdot 6$ & $22 \cdot \mathbf{r}$ & I3.2 & $5 \cdot 7$ & 0.3 \\
\hline
\end{tabular}

* PAR. = General paresis. T.P. = Tabo-paresis. 


\section{BRITISH JOURNAL OF VENEREAL DISEASES}

TABLE II.-ACQUIRED INFECTION-WOMEN

Cases of Neurosyphilis as shown below, Years when Treatment Commenced, Present State, and Numbers showing

\section{Intolerance}

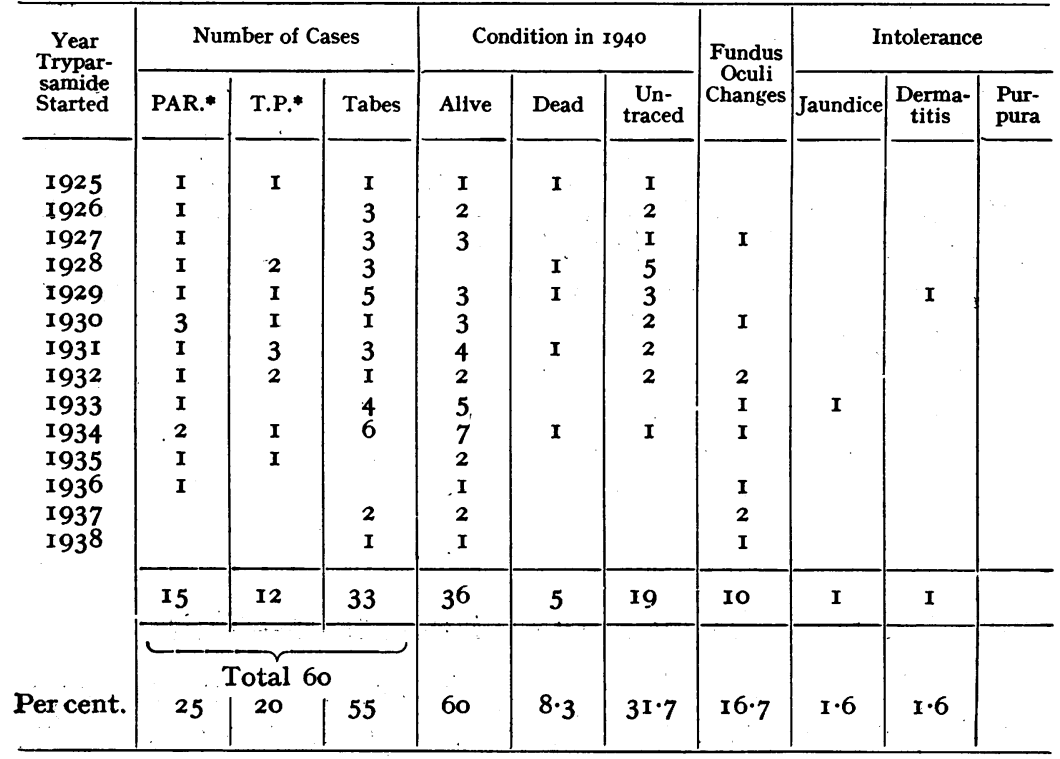

* PAR. = General paresis. T.P. = Tabo-paresis.

Table III.-Living Paretics-Men. Ages, Treatment and Present Condition

\begin{tabular}{|c|c|c|c|c|c|c|c|c|c|c|}
\hline \multirow{2}{*}{$\begin{array}{l}\text { Year } \\
\text { Trypar- } \\
\text { samide } \\
\text { Started }\end{array}$} & \multicolumn{4}{|c|}{$\begin{array}{l}\text { Age Group at Commencement } \\
\text { of Treatment }\end{array}$} & \multirow{2}{*}{$\begin{array}{c}\text { Average } \\
\text { Amount of } \\
\text { Tryparsamide } \\
\text { Administered } \\
\text { in Grams }\end{array}$} & \multirow{2}{*}{ Malaria } & \multicolumn{4}{|c|}{ Condition in 1940} \\
\hline & $20-40$ & $40-50$ & $50-60$ & Over $6 n$ & & & ڤ్ & 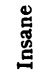 & $\begin{array}{l}\text { Able to } \\
\text { Work }\end{array}$ & $\begin{array}{c}\text { Un- } \\
\text { traced }\end{array}$ \\
\hline \multirow{12}{*}{$\begin{array}{l}1925 \\
1926 \\
1927 \\
1928 \\
1929 \\
1930 \\
1931 \\
1932 \\
1933 \\
1934 \\
1935 \\
1936 \\
1937 \\
1938\end{array}$} & 2 & & & & 336 & I & 2 & & 2 & \\
\hline & $\begin{array}{l}3 \\
\mathbf{I}\end{array}$ & I & I & & $\begin{array}{l}241 \\
158\end{array}$ & $\begin{array}{l}\text { I } \\
2\end{array}$ & 3 & & 3 & $\begin{array}{l}\mathbf{I} \\
2\end{array}$ \\
\hline & 4 & I & 3 & & 227 & 3 & 6 & 2 & 6 & \\
\hline & 3 & I & & & 174 & 2 & 3 & & 3 & I \\
\hline & & 4 & & I & 197 & 3 & 3 & & 3 & 2 \\
\hline & 3 & & & & 222 & 2 & I & I & I & I \\
\hline & 2 & 4 & I & & 225 & 4 & 5 & I & 5 & I \\
\hline & I & 2 & I & & I39 & I & I & & I & 3 \\
\hline & I & 2 & I & & 78 & 2 & 3 & & 3 & I \\
\hline & 2 & I & & & II4 & 3 & 2 & I & 2 & \\
\hline & $\mathbf{I}$ & & & & 3 & I & I & & $\mathbf{I}$ & \\
\hline & 20 & 19 & 7 & I & & 25 & 30 & 5 & 30 & 12 \\
\hline
\end{tabular}

Total in all groups $=47$.

Percentage able to work $\doteq 63.8$. 80 


\section{TRYPARSAMIDE IN NEUROSYPHILIS}

Table IV.-Living Paretics-Women

Ages, Treatment and Present Condition

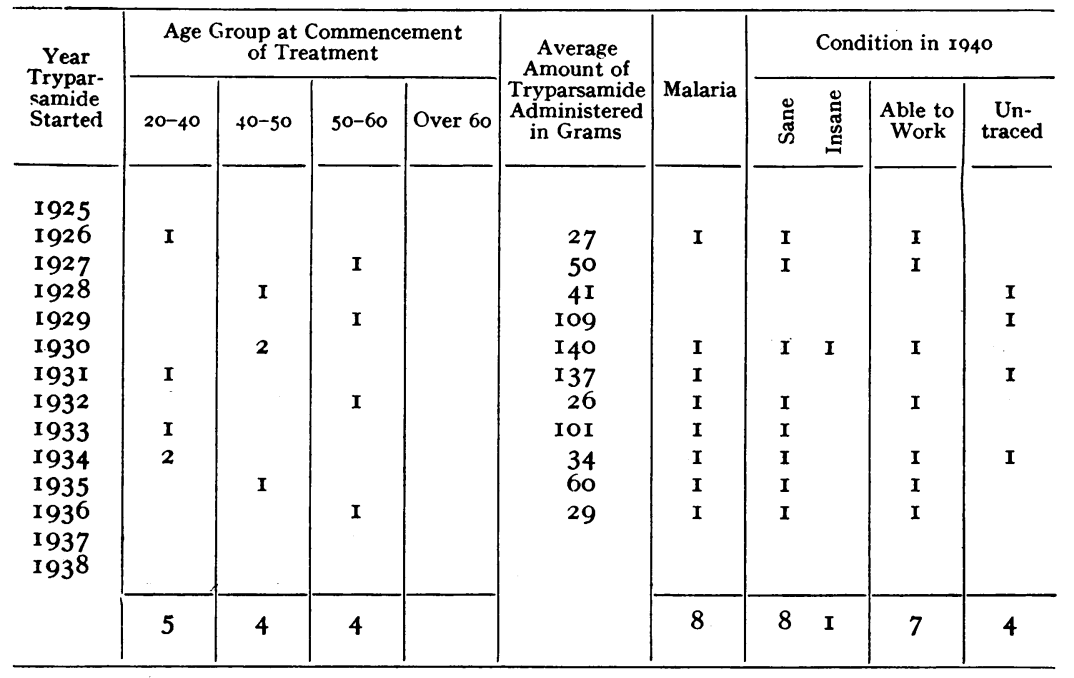

Total in all groups $=\mathrm{r} 3 . \quad$ Percentage able to work $=53.8$.

TABle V.-Living TABo-Paretics-Men Ages, Treatment and Present Condition.

\begin{tabular}{|c|c|c|c|c|c|c|c|c|}
\hline \multirow{2}{*}{$\begin{array}{c}\text { Year } \\
\text { Tryparsamide } \\
\text { Started }\end{array}$} & \multicolumn{4}{|c|}{$\begin{array}{l}\text { Age Group at Commencement of } \\
\text { Treatment }\end{array}$} & \multirow{2}{*}{$\begin{array}{c}\text { Average Amount } \\
\text { of Tryparsamide } \\
\text { Administered in } \\
\text { Grams }\end{array}$} & \multirow{2}{*}{ Malaria } & \multicolumn{2}{|c|}{ Condition in 1940} \\
\hline & $20-40$ & $40-50$ & $50-60$ & Over 60 & & & $\begin{array}{l}\text { Able to } \\
\text { Work }\end{array}$ & Untraced \\
\hline \multirow{12}{*}{$\begin{array}{l}1925 \\
1926 \\
1927 \\
1928 \\
1929 \\
1930 \\
1931 \\
1932 \\
1933 \\
1934 \\
1935 \\
1936 \\
1937 \\
1938\end{array}$} & $\begin{array}{l}2 \\
\mathbf{I}\end{array}$ & I & & & $\begin{array}{l}268 \\
670\end{array}$ & $\begin{array}{l}2 \\
\mathbf{I}\end{array}$ & 2 & $\mathbf{I}$ \\
\hline & 3 & $\begin{array}{l}\mathbf{I} \\
2\end{array}$ & I & & $\begin{array}{r}36 \\
304\end{array}$ & 2 & I & 3 \\
\hline & & & I & & 136 & $\mathbf{I}$ & & \\
\hline & 2 & & & & I 53 & 2 & I & \\
\hline & 2 & 2 & & & 324 & 2 & 3 & \\
\hline & 6 & I & & & $12 I$ & & I & 4 \\
\hline & & 2 & & & 166 & & I & I \\
\hline & I & 3 & & & 180 & I & 4 & \\
\hline & I & 2 & I & $\mathbf{I}$ & 39 & I & 2 & 2 \\
\hline & 2 & I & & & 124 & & I & \\
\hline & & $\mathbf{I}$ & $\mathbf{I}$ & & 6 & $\mathbf{I}$ & I & I \\
\hline & 20 & 16 & 4 & I & & 14 & I 8 & I4 \\
\hline
\end{tabular}

Total in all groups $=4 \mathrm{I} . \quad$ Percentage able to work $=43.9$. $8 \mathrm{I}$ 


\section{BRITISH JOURNAL OF VENEREAL DISEASES}

\section{TABle VI.-Living TABO-PARETICS-Women \\ Ages, Treatment and Present Condition}

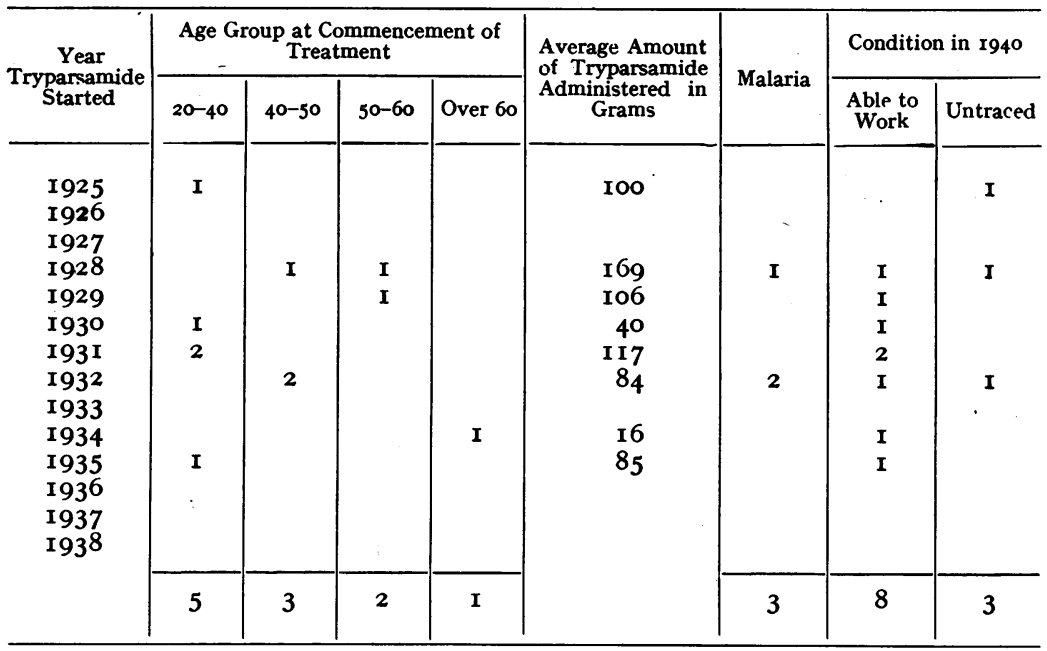

Total in all groups $=$ II. Percentage able to work $=72 \cdot 7$.

\section{TABle VII.-Living TABetics-Men}

\section{Ages, Treatment and Present Condition}

\begin{tabular}{|c|c|c|c|c|c|c|c|c|}
\hline \multirow{2}{*}{$\begin{array}{c}\text { Year } \\
\text { Tryparsamide } \\
\text { Started }\end{array}$} & \multicolumn{4}{|c|}{$\begin{array}{l}\text { Age Group at Commencement of } \\
\text { Treatment }\end{array}$} & \multirow{2}{*}{$\begin{array}{l}\text { Average Amount } \\
\text { ot Tryparsamide } \\
\text { Administered in } \\
\text { Grams }\end{array}$} & \multirow{2}{*}{ Malaria } & \multicolumn{2}{|c|}{ Condition in 1940} \\
\hline & $20-40$ & $40-50$ & $50-60$ & Over 60 & & & $\begin{array}{l}\text { Able to } \\
\text { Work }\end{array}$ & Untraced \\
\hline $\begin{array}{l}1925 \\
1926\end{array}$ & I & $\begin{array}{l}\mathbf{I} \\
2\end{array}$ & & & $\begin{array}{r}94 \\
306\end{array}$ & & 2 & $\mathbf{I}$ \\
\hline I927 & 2 & 4 & 2 & & 231 & & 3 & 4 \\
\hline I928 & 4 & 2 & 5 & & 224 & & 4 & 5 \\
\hline I 929 & 7 & 3 & 2 & & 198 & & 6 & 3 \\
\hline 1930 & I & 4 & 4 & $\mathbf{I}$ & I 78 & & 8 & I \\
\hline r931 & 2 & I0 & 9 & I & 198 & I & I I & 3 \\
\hline 1932 & 2 & 4 & 4 & $\mathbf{I}$ & 174 & & 4 & 3 \\
\hline I 933 & 2 & I I & 4 & 2 & 80 & & 7 & 8 \\
\hline 1934 & 3 & 6 & 3 & I & 127 & I & 9 & 3 \\
\hline I 935 & 4 & 4 & 5 & & 117 & 2 & 8 & 5 \\
\hline I936 & & 6 & 3 & & I37 & & 6 & 2 \\
\hline \multirow{3}{*}{$\begin{array}{l}1937 \\
1938\end{array}$} & 3 & 5 & I & & 75 & I & 4 & 4 \\
\hline & & 1 & & & 92 & I & & I \\
\hline & 31 & 63 & 42 & 6 & & & 72 & 43 \\
\hline
\end{tabular}

Total in all groups $=142 . \quad$ Percentage able to work $=50 \cdot 7$. 82 


\section{TRYPARSAMIDE IN NEUROSYPHILIS}

Table VIII.-Living Tabetics-Women Ages, Treatment and Present Condition

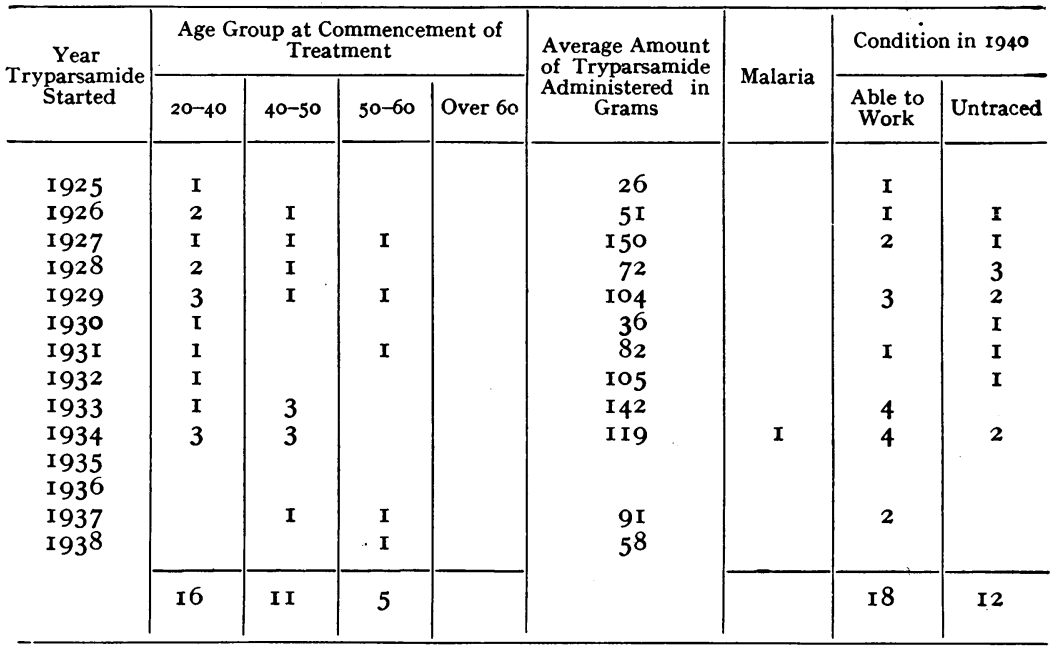

Total in all groups $=32$. Percentage able to work $=56 \cdot 2$.

Table IX.-Congenital Infection-Males

Neurosyphilitics as showen, Ages, Treatment and Present Condition

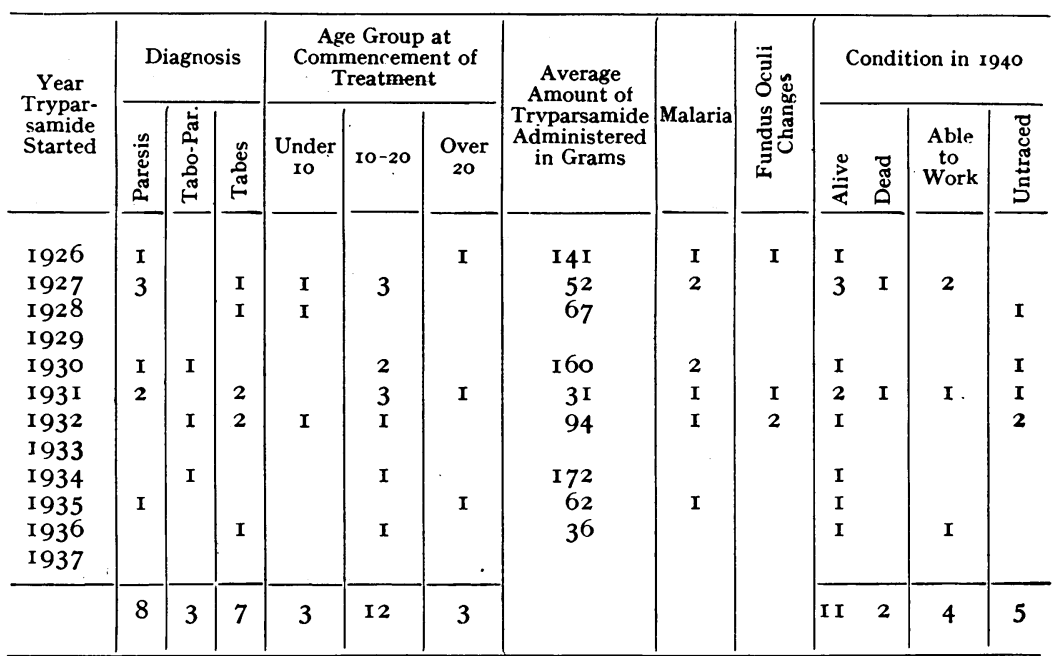

Total in all groups $=\mathrm{x} 8$.

Percentage alive $=6 \mathrm{I} \cdot \mathrm{I}$.

Percentage able to work $=\mathbf{2 2 \cdot 2}$.

83 


\section{Table X.-Congenital Infection-Females Neurosyphilitics as under, Ages, Treatment, and Present Condition}

\begin{tabular}{|c|c|c|c|c|c|c|c|c|c|c|c|c|}
\hline \multirow{2}{*}{$\begin{array}{l}\text { Year } \\
\text { Trypar- } \\
\text { samide } \\
\text { Started }\end{array}$} & \multicolumn{3}{|c|}{ Diagnosis } & \multicolumn{3}{|c|}{$\begin{array}{l}\text { Age Group at } \\
\text { Commencement of } \\
\text { Treatment }\end{array}$} & \multirow{2}{*}{$\begin{array}{c}\text { Average } \\
\text { Amount of } \\
\text { Tryparsamide } \\
\text { Administered } \\
\text { in Grams }\end{array}$} & \multirow[b]{2}{*}{ Malaria } & \multirow{2}{*}{ 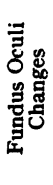 } & \multicolumn{3}{|c|}{ Condition in 1940} \\
\hline & 离 & 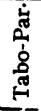 & 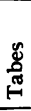 & $\begin{array}{l}\text { Under } \\
\text { ro }\end{array}$ & $10-20$ & $\begin{array}{c}\text { Over } \\
20\end{array}$ & & & & $\stackrel{0}{\rightleftarrows}$ & $\begin{array}{c}\text { Able } \\
\text { to } \\
\text { Work }\end{array}$ & 总 \\
\hline \multirow{8}{*}{$\begin{array}{l}1926 \\
1927 \\
1928 \\
1929 \\
1930 \\
1931 \\
1932 \\
1933 \\
1934\end{array}$} & I & & I & & I & I & \multirow{8}{*}{$\begin{array}{c}100 \\
44 \\
14 \\
65 \\
1 \cdot 3 \\
67 \\
32 \\
5\end{array}$} & \multirow[t]{8}{*}{ I } & \multirow{8}{*}{$\begin{array}{l}\mathbf{I} \\
\mathbf{I}\end{array}$} & \multirow{2}{*}{ I. } & & I \\
\hline & I & & I & & I & I & & & & & & I \\
\hline & I & I & I & I & I & I & & & & \multirow[t]{2}{*}{ I } & & 2 \\
\hline & $\mathbf{I}$ & & & I & & & & & & & & I \\
\hline & $\mathbf{I}$ & & I & & 2 & & & & & & & \\
\hline & & & 2 & & $\mathbf{I}$ & I & & & & & & I \\
\hline & & & & & & & & & & \multirow{2}{*}{$\overline{5}$} & & \\
\hline & 6 & I & 6 & 3 & 6 & 4 & & & & & & 8 \\
\hline
\end{tabular}

Total in all groups $=13 . \quad$ Percentage alive $=38 \cdot 4$.

TABLE XI.-OPTIC ATROPHY-ACQUIRED INFECTIONMALES

\begin{tabular}{|c|c|c|c|c|c|c|c|c|}
\hline \multirow{2}{*}{$\begin{array}{l}\text { Amoint of } \\
\text { Tryparsamide } \\
\text { Administered } \\
\text { in Grams }\end{array}$} & \multirow{2}{*}{$\begin{array}{l}\text { Number } \\
\text { of Cases }\end{array}$} & \multicolumn{3}{|c|}{$\begin{array}{l}\text { Optic Atrophy Present when } \\
\text { Tryparsamide Started }\end{array}$} & \multirow{2}{*}{$\begin{array}{c}\text { Optic } \\
\text { Atrophy } \\
\text { not } \\
\text { Present } \\
\text { when } \\
\text { Trypar- } \\
\text { samide } \\
\text { Started }\end{array}$} & \multicolumn{3}{|c|}{ Degree of Ultimate Damage } \\
\hline & & Slight & Moderate & Severe & & Slight & Moderate & Severe \\
\hline $\begin{array}{l}\text { Under } 10 \mathrm{gm} \text {. } \\
\text { 10 to } 30 \mathrm{gm} \text {. } \\
30 \text { to } 100 \mathrm{gm} \text {. } \\
\text { Over } 100 \mathrm{gm} \text {. }\end{array}$ & $\begin{array}{r}4 \\
7 \\
20 \\
30\end{array}$ & $\begin{array}{l}2 \\
4 \\
6\end{array}$ & $\begin{array}{l}\mathbf{I} \\
\mathrm{I} \\
\mathrm{I} \\
8\end{array}$ & $\begin{array}{l}2 \\
I \\
9 \\
6\end{array}$ & $\begin{array}{r}1 \\
3 \\
6 \\
10\end{array}$ & $\begin{array}{l}3 \\
5\end{array}$ & $\begin{array}{l}2 \\
6\end{array}$ & $\begin{array}{r}4 \\
7 \\
13 \\
19\end{array}$ \\
\hline Totals & 61 & 12 & I I & 18 & 20 & 8 & 8 & 45 \\
\hline Percentages & & & $\begin{array}{l}41 \\
67 \cdot 2\end{array}$ & & $32 \cdot 8$ & I3· I & I3:I & $73 \cdot 7$ \\
\hline
\end{tabular}


TABLE XII.-OPTIC ATROPHY-ACQUIRED INFECTIONFemales

\begin{tabular}{|c|c|c|c|c|c|c|c|c|}
\hline \multirow{2}{*}{$\begin{array}{l}\text { Amount of } \\
\text { Tryparsamide } \\
\text { Administered } \\
\text { in Grams }\end{array}$} & \multirow{2}{*}{$\begin{array}{l}\text { Number } \\
\text { of Cases }\end{array}$} & \multicolumn{3}{|c|}{$\begin{array}{l}\text { Optic Atrophy Present when } \\
\text { Tryparsamide Started }\end{array}$} & \multirow{2}{*}{$\begin{array}{c}\text { Optic } \\
\text { Atrophy } \\
\text { not } \\
\text { Present } \\
\text { when } \\
\text { Trypar- } \\
\text { samide } \\
\text { Started }\end{array}$} & \multicolumn{3}{|c|}{ Degree of Ultimate Damage } \\
\hline & & Slight & Moderate & Severe & & Slight & Moderate & Severe \\
\hline $\begin{array}{l}\text { Under ro gm. } \\
\text { ro to } 30 \mathrm{gm} \text {. } \\
30 \text { to } 100 \mathrm{gm} \text {. } \\
\text { Over } 100 \mathrm{gm} \text {. }\end{array}$ & $\begin{array}{l}\text { I } \\
2 \\
4\end{array}$ & $\begin{array}{l}\mathbf{I} \\
3\end{array}$ & $\mathbf{I}$ & $\mathbf{I}$ & I & 4 & I & 2 \\
\hline Totals & 7 & 4 & $\therefore \mathbf{I}$ & $\mathbf{I}$ & $\mathbf{I}$ & 4 & $\mathbf{I}$ & 2 \\
\hline Percentages & & & $\begin{array}{l}6 \\
85 \cdot 7\end{array}$ & & $14 \cdot 3$ & $57: I$ & $14 \cdot 2$ & $28 \cdot 6$ \\
\hline
\end{tabular}

Table XIII.-Optic Atrophy-Congenital Infection -MALES

\begin{tabular}{|c|c|c|c|c|c|c|c|c|}
\hline \multirow{2}{*}{$\begin{array}{l}\text { Amount of } \\
\text { Tryparsamide } \\
\text { Administered } \\
\text { in Grams }\end{array}$} & \multirow{2}{*}{$\begin{array}{l}\text { Number } \\
\text { of Cases }\end{array}$} & \multicolumn{3}{|c|}{$\begin{array}{l}\text { Optic Atrophy Present when } \\
\text { Tryparsamide Started }\end{array}$} & \multirow{2}{*}{$\begin{array}{c}\text { Optic } \\
\text { Atrophy } \\
\text { not } \\
\text { Present } \\
\text { when } \\
\text { Trypar- } \\
\text { samide } \\
\text { Started }\end{array}$} & \multicolumn{3}{|c|}{ Degree of Ultimate Damage } \\
\hline & & Slight & Moderate & Severe & & Slight & Moderate & Severe \\
\hline $\begin{array}{l}\text { Under ro gm. } \\
\text { Io to } 30 \mathrm{gm} \text {. } \\
\text { 30 to } 100 \mathrm{gm} \text {. } \\
\text { Over } 100 \mathrm{gm} \text {. }\end{array}$ & $\mathbf{I}$ & & $\mathbf{I}$ & & I & & ${ }^{\cdot}$ & I \\
\hline Totals & 2 & & $\mathbf{I}$ & & $\mathbf{I}$ & & $\mathbf{I}$ & $\mathbf{I}$ \\
\hline Percentages & & & $\begin{array}{r}I \\
50\end{array}$ & & 50 & & 50 & 50 \\
\hline
\end{tabular}


BRITISH JOURNAL OF VENEREAL DISEASES

TABLe XIV.-Optic Atrophy-Congenital Infection -Females

\begin{tabular}{|c|c|c|c|c|c|c|c|c|}
\hline \multirow{2}{*}{$\begin{array}{l}\text { Amount of } \\
\text { Tryparsamide } \\
\text { Administered } \\
\text { in Grams }\end{array}$} & \multirow{2}{*}{$\begin{array}{l}\text { Number } \\
\text { of Cases }\end{array}$} & \multicolumn{3}{|c|}{$\begin{array}{l}\text { Optic Atrophy Present when } \\
\text { Tryparsamide Started }\end{array}$} & \multirow{2}{*}{$\begin{array}{c}\text { Optic } \\
\text { Atrophy } \\
\text { not } \\
\text { Present } \\
\text { when } \\
\text { Trypar- } \\
\text { samide } \\
\text { Started }\end{array}$} & \multicolumn{3}{|c|}{ Degree of Ultimate Damage } \\
\hline & & Slight & Moderate & Severe & & Slight & Moderate & Severe \\
\hline $\begin{array}{l}\text { Under Io gm. } \\
\text { 1o to } 30 \mathrm{gm} \text {. } \\
\text { 30 to } 100 \mathrm{gm} \text {. } \\
\text { Over } 100 \mathrm{gm} \text {. }\end{array}$ & $\begin{array}{l}\mathbf{I} \\
\mathbf{I} \\
\mathbf{I}\end{array}$ & & $\begin{array}{l}\mathbf{I} \\
\mathbf{I}\end{array}$ & I & & & $\begin{array}{l}\text { I } \\
\text { I }\end{array}$ & I \\
\hline Totals & 3 & & 2 & I & 0 & & 2 & I \\
\hline Percentages & & & $\begin{array}{r}3 \\
\text { roo }\end{array}$ & & & & $66 \cdot 6$ & $33 \cdot 3$ \\
\hline
\end{tabular}

Table XV.-Tryparsamide in Pregnancy-Optic ATROPHy IN THE Child

\begin{tabular}{c|c|c|c}
\hline Case Number & $\begin{array}{c}\text { Amount of Trypars- } \\
\text { amide given during } \\
\text { the Pregnancy in } \\
\text { Grams }\end{array}$ & $\begin{array}{c}\text { Time between Last } \\
\text { Dose and Confine- } \\
\text { ment in Days }\end{array}$ & $\begin{array}{c}\text { Optic Atrophy } \\
\text { in the Child }\end{array}$ \\
\hline & 23 & 6 & Nil \\
I245 & 36 & I9 & Nil \\
9.2541 & $38 \cdot 5$ & No record & Nil \\
947 & $1 \cdot 8$ & 22 & Nil \\
1035 & & & \\
\hline
\end{tabular}

